\title{
EFFICIENCY OF BIOLOGICAL PHOSPHORUS REMOVAL BY FILAMENTOUS BACTERIA
}

\author{
EFEKTYWNOŚĆ BIOLOGICZNEGO USUWANIA FOSFORU \\ PRZEZ BAKTERIE NITKOWATE
}

\begin{abstract}
Phosphorus removal in wastewater treatment plant is carried out by chemical precipitation, advanced biological treatment or a combination of both. One of the biggest problems with high concentration of phosphorus in water environment is eutrophication. Activated sludge flocs have a heterogeneous structure, which consist of a variety of microorganisms. Filamentous bacteria are normally present in the activated sludge and have ability to assimilation of phosphorus. In this study phosphorus accumulation by isolated filamentous bacteria from activated sludge foam was present.
\end{abstract}

Keywords: filamentous microorganisms, wastewater, activated sludge foam, phosphorus

\section{Introduction}

Phosphates are present in high concentrations in wastewaters and can be removed through chemical precipitation, advanced biological treatment or a combination of both. High concentration of phosphorus can lead to many water quality problems, including e.g.: increase of the treatment cost, lowering the recreational values, loss of livestock and possible sublethal effects of algal [1]. Conventional activated sludge microorganisms (mixed liquor suspended solids, or MLSS) contain 1.5 to $2.0 \%$ phosphorus (dry weight measure). Conventional activated sludge processes achieve removal efficiency of approximately $20 \%$ [2].

In the biological phosphorus removal natural capacity of phosphorus accumulation by activated sludge microorganisms has been used. Activated sludge flocs have a heterogeneous structure, which consist of a variety of microorganisms as well as organic and inorganic particles and dead cells surrounded by extracellular polymeric substances $[3,4]$. Filamentous bacteria are normally present in the activated sludge and have ability to assimilation of phosphorus, which enters into the composition of several macromolecules in the cell, but same microorganisms (e.g. Acinetobacter, Pseudomonas, Aerobacter,

\footnotetext{
${ }^{1}$ Institute of Engineering and Environmental Protection, Faculty of Materials, Civil and Environmental Engineering, University of Bielsko-Biala, ul. Willowa 2, 43-300 Bielsko-Biała, Poland, phone +48 338279157 , email: amachnicka@ath.bielsko.pl,kgrubel@ath.bielsko.pl

* Corresponding author: kgrubel@ath.bielsko.pl
} 
Moraxella, E. coli, Mycobacterium, Corynebacterium) have the ability to store phosphorus as polyphosphates in volutin granules.

Since Fuhs and Chen [5] first described Acinetobacter spp. as a microorganism playing an important role in enhanced biological phosphorous removal processes, most subsequent studies have focused on biological reactions and other organisms participating in biological phosphorous removal. Bacterial biomass in conventional activated sludge systems treating municipal sewage usually contains $2-3 \%$ of phosphorous. Designed for nutrients removal activated sludge can accumulate as much as $8 \%$ of phosphorous. Finally phosphorous is removed from the treated sewage with the surplus activated sludge.

Many wastewater treatment plants have problems in the stage of biological treatment, which are related to the copious growth of filamentous microorganisms. Under specific conditions they proliferate to such an extent that they markedly affect the treatment plant performance causing sludge bulking or foaming. Besides the excessive growth of these bacteria can cause potential problems with the sludge settling that reduce the efficiency of the wastewater treatment plants.

In order to control the growth of these problematic bacteria, their identification has been required. More than 30 different filamentous bacterial morphotypes have been described based on their morphology $[6,7]$.

Activated sludge systems designed for enhanced nutrients removal are based on the principle of altering anaerobic and aerobic conditions for growth of microorganisms with a high capacity of phosphorous accumulation. Sometimes, to avoid the return of large parts of accumulated phosphorous in the processes of sludge conditioning chemical precipitation is often applied.

\section{Materials and methods}

Wastewater and foam samples were taken from a large municipal wastewater treatment plant in Bielsko-Biala. The amount of treated wastewater is approximately $90,000 \mathrm{~m}^{3} / \mathrm{d}$. Solid retention time (SRT) is about 14 days and the concentration of mixed liquor suspended solids (MLSS) fluctuates between 4.3-4.7 $\mathrm{g} / \mathrm{dm}^{3}$.

Characterization of sterile wastewater

\begin{tabular}{|c|c|c|}
\hline Parameter & Unit & Wastewater \\
\hline $\mathrm{pH}$ & - & 7.14 \\
\hline $\mathrm{T}$ & {$\left[{ }^{\circ} \mathrm{C}\right]$} & 20.1 \\
\hline ORP & {$[\mathrm{mV}]$} & 209 \\
\hline Oxygen dissolved & {$\left[\mathrm{mg} \mathrm{O}_{2} / \mathrm{dm}^{3}\right]$} & 3.4 \\
\hline Ammonia nitrogen & {$\left[\mathrm{mg} \mathrm{N}_{\mathrm{NH} 4} / \mathrm{dm}^{3}\right]$} & 29.6 \\
\hline Nitrites & {$\left[\mathrm{mg} \mathrm{N}_{\mathrm{NO} 2} / \mathrm{dm}^{3}\right]$} & 0.18 \\
\hline Nitrates & {$\left[\mathrm{mg} \mathrm{N}_{\mathrm{NO} 3} / \mathrm{dm}^{3}\right]$} & 2.5 \\
\hline Phosphates & {$\left[\mathrm{mg} \mathrm{PO}_{4}{ }^{3-} / \mathrm{dm}^{3}\right]$} & 59.8 \\
\hline Phosphorus & {$\left[\mathrm{mg} \mathrm{P}^{2} \mathrm{dm}^{3}\right]$} & 19.8 \\
\hline COD & {$\left[\mathrm{mg} \mathrm{O}_{2} / \mathrm{dm}^{3}\right]$} & 449 \\
\hline Calcium & {$\left[\mathrm{mg} \mathrm{Ca}^{2+1} \mathrm{dm}^{3}\right]$} & 60.1 \\
\hline Magnesium & {$\left[\mathrm{mg} \mathrm{Mg}^{2+1} \mathrm{dm}^{3}\right]$} & 19.0 \\
\hline Potassium & {$\left[\mathrm{mg} \mathrm{K}^{+1} \mathrm{dm}^{3}\right]$} & 35.6 \\
\hline
\end{tabular}

The wastewater and foam samples were taken from the nitrification chamber. Samples were put in the plastic containers by scoop and then they were immediately (about $20 \mathrm{~min}$ ) 
taken to the laboratory and sterilized. Sterile wastewater used in the study was characterized by the parameters presented in Table 1. Prepared wastewater allowed for good growth of filamentous poly-P bacteria.

Samples were analyses for: $\mathrm{pH}$, temperature, redox (oxidation - reduction potential ORP), phosphates, phosphorus, nitrogen $\left(\mathrm{N}_{-} \mathrm{NO}_{3}, \mathrm{~N}-\mathrm{NO}_{2}, \mathrm{~N}-\mathrm{NH}_{4}\right)$, chemical oxygen demand (COD), oxygen dissolved (DO), metal ions: calcium, magnesium and potassium and density of bacteria. The wastewater was determined in accordance to the Standards Methods [8] procedures, using a spectrophotometer HACH DR 4000. Concentration of potassium, magnesium and calcium were determined on an atomic absorption analysis instrument - AAnalyst 100 Perkin Elmer.

The foam samples were also analyses in microbiological way and filamentous microorganisms were isolated according procedure given by Machnicka [9]. In morphological analyses were used a bright field and contrast phase microscope coupled with a camera was used for observations. The microscope used - Nikon Alphaphot - 2 YS coupled with camera Panasonic GP-KR 222 allowed also for size measurements by a programme Lucia - ScMeas Version 4.51. Samples for microscopic investigations were stained according to the Gram and Neisser methods.

After identifications of filamentous poly-P bacteria, five reactors, of $500 \mathrm{~cm}^{3}$ volume each, were filled with wastewater. Reactors including sewages have been sterilized for 30 minutes in an autoclave at a temperature of $121^{\circ} \mathrm{C}$, and a pressure of $150 \mathrm{kPa}$.

Filamentous poly-P bacteria were analyzed on the basis of biochemical API ZYM test (bioMérieux Polska Sp. $\mathrm{z}$ o.o.), which are semi quantitative micro-methods, for the assessment of enzymatic activity and bacteriological selective agar and selective were used. Species choice of activated sludge and identification will be aim of different article.

\section{Results and discussion}

Filamentous microorganisms are dominantly present in the scum floating over bioreactors surface (Fig. 1). Confirmation of phosphorus accumulation by microorganisms are visible glowing volutin granules which are noticeable in the cells of filamentous bacteria of foam (Fig. 1).

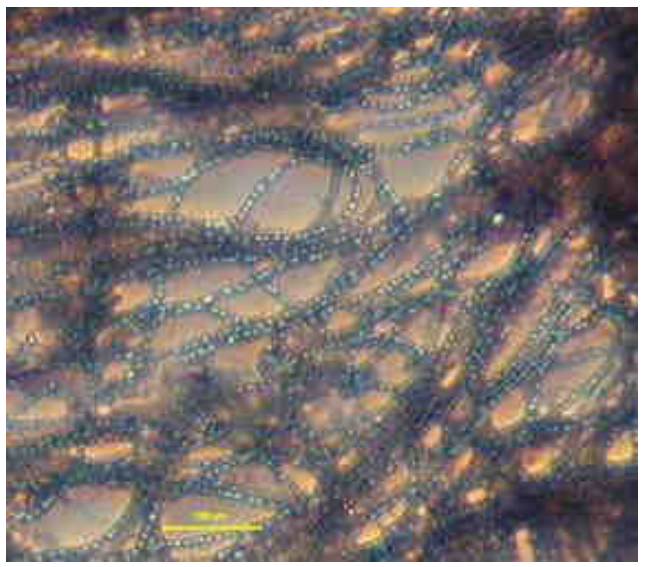

Fig. 1. Filamentous poly-P bacteria in the foam of activated sludge - Neisser method (contrast phase) [authors] 
The isolated species have had a similar morphological characteristic. In all of the examined foam samples, among the filamentous microorganisms there was a domination of not branched forms, while the branched - „tree-like” and dichotomic forms were less frequently present (Figs. 2-6 - Gram-method, bright field). Among the isolated filamentous poly-P bacteria, basing on the cultivated, morphological and biochemical tests, the following species have been distinguished: Microthrix parvicella (Fig. 2), Nocardia amarae (Fig. 3), Nocardia sp. (J-27), (Fig. 4), Nocardia pinensis (Fig. 5), Rhodococcus chubuensis (Fig. 6).

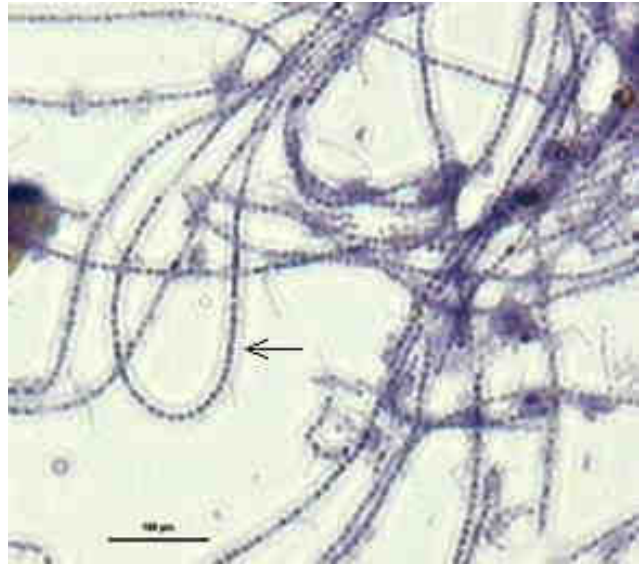

Fig. 2. Microthrix parvicella [authors]

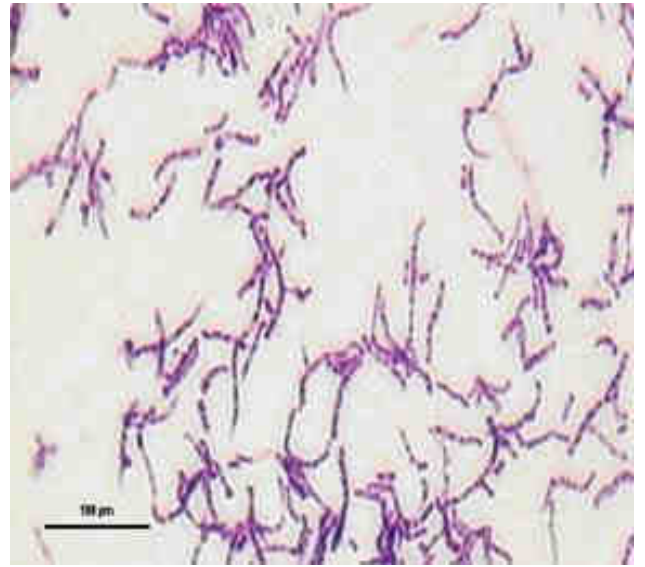

Fig. 3. Nocardia amarae [authors]

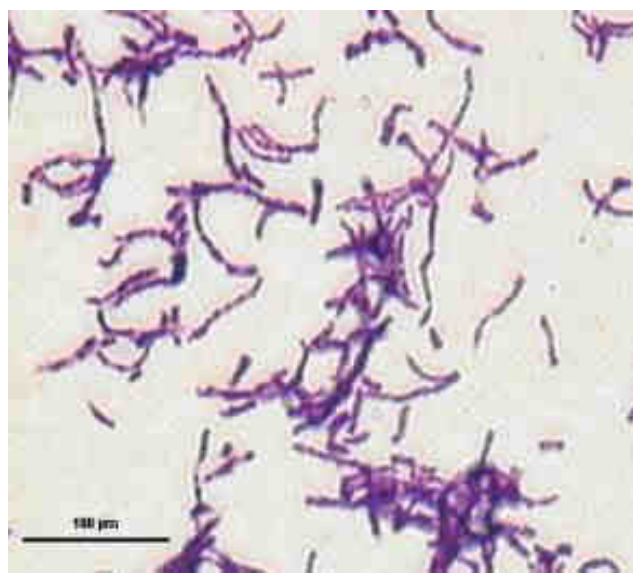

Fig. 4. Nocardia sp. (J - 27) [authors]

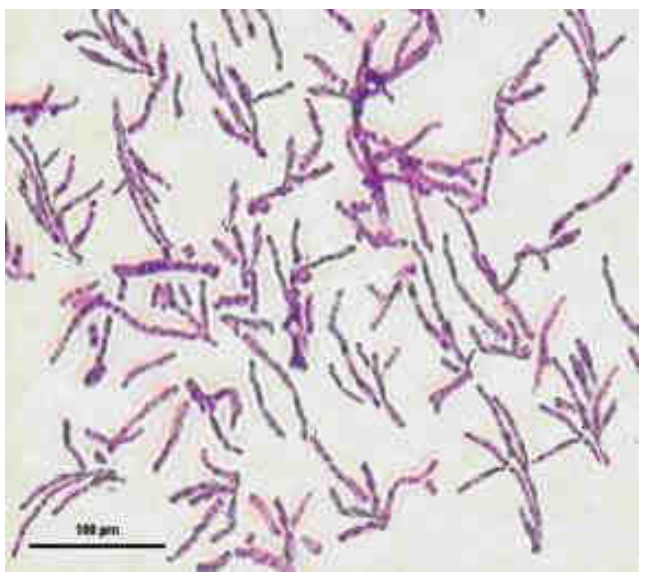

Fig. 5. Nocardia pinensis [authors]

The results presented highlight phosphorus uptake by filamentous microorganisms dominantly present in the scum, floating over bioreactors surface. On the basis of chemical determinations it was concluded that the phosphorous uptake was in surplus to that required for biomass synthesis (Fig. 7). Under aerobic conditions increase of stored phosphorous by 
filamentous microorganisms was measured in parallel to the phosphates decrease in the liquid. The determined removal of phosphorous from sewage was supported by the results of microscopic observations of bacteria stained according to Neisser tests (Fig. 1). Volutin granules which are noticeable in the cells of filamentous bacteria of foam are confirming accumulation of phosphorous by the filamentous microorganisms.

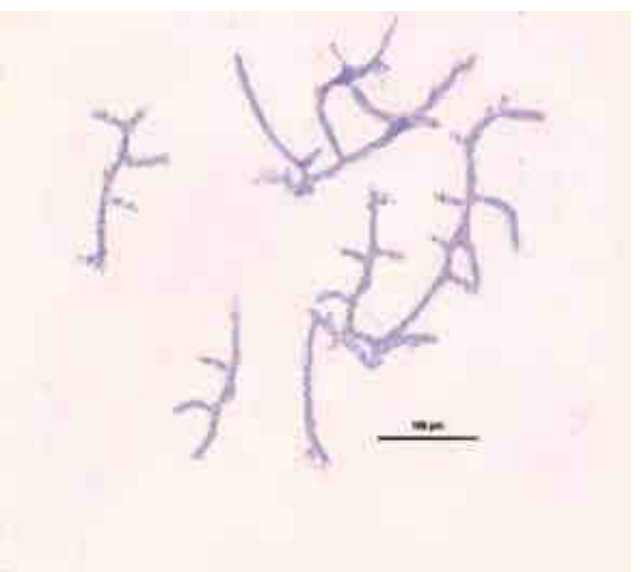

Fig. 6. Rhodococcus chubuensis [authors]

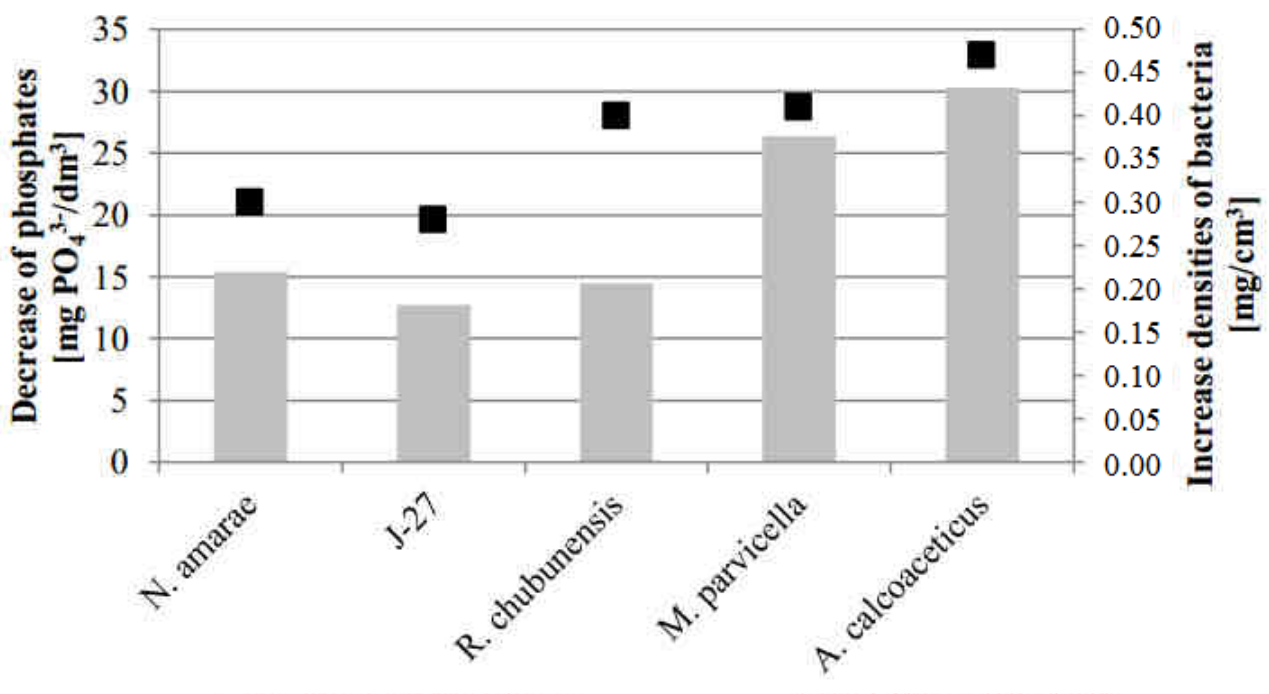

Decrease of phosphates

Fig. 7. Changes of phosphates concentration and densities of bacteria

Microthrix parvicella was particularly active in phosphorous accumulation (Fig. 7). Microthrix parvicella dominantly present in the floating scum over the bioreactors surface, 
has had a capacity of phosphorous uptake and accumulation similar to that of Acinetobacter calcoaceticus (Fig. 7).

In the stage of logarithmic growth Microthrix parvicella and Nocardia amarae have shown a distinctly higher ability of phosphorous accumulation in comparison to the ability of volutin granules storage by Acinetobacter calcoaceticus (Fig. 7).

According to various authors $[10,11]$ microorganism's cell comprises $70-86 \%$ of water and the hydration depends mainly on: the quantity of materials up, the composition of the culture medium, the growth phase and characteristics of species. Supposing that the cell organisms tested contained only $75 \%$ of the water, and not taking into account weight of the inoculum surrounding the cells, after the calculation can be demonstrated that the phosphorous accumulated comprise from 5.0 to $8.7 \%$ by dry weight of cells (Table 2). Additionally, converting the weight of accumulated phosphorous per biomass unit of bacteria $(1 \mathrm{mg})$, could be found that these microorganisms assimilated from 0.017 to $0.022 \mathrm{mg} \mathrm{P} / \mathrm{mg}$ biomass (Table 2).

Table 2.

Content of phosphorous in biomass

\begin{tabular}{|c|c|c|}
\hline Bacteria species & $\begin{array}{c}\text { Accumulated phosporous } \\
\text { [mg P/mg biomass] }\end{array}$ & $\begin{array}{c}\text { Percentage of phosphorous } \\
\text { in biomass [\%] }\end{array}$ \\
\hline Nocardia amarae & 0.017 & 6.7 \\
\hline Nocardia J -27 & 0.014 & 5.7 \\
\hline Rhodococcus chubuensis & 0.012 & 5.0 \\
\hline Microthrix parvicella & 0.022 & 8.7 \\
\hline Acinetobacter calcoaceticus & 0.021 & 8.5 \\
\hline
\end{tabular}

\section{Conclusions}

Filamentous bacteria have ability to phosphorous accumulation in form of volutin granules. Among analyzed microorganisms highest storage properties characterized by Microthrix parvicella (filamentous bacteria) and Acinetobacter calcoaceticus (not filamentous bacteria). Percentage of phosphorous in biomass was 8.7 and $8.5 \%$, respectively. Though technological troubles caused by filamentous microorganisms, they could be used for the of biological phosphorous removal processes with good efficiency.

\section{References}

[1] Nedjah N, Laskri N. Phosphorus removal from urban wastewater via chemical and combined treatment against eutrophication of receiving environments. Int J Service, Sci Technol. 2015;8(7):303-312. DOI: 10.14257/ijunesst.2015.8.7.31.

[2] Yeoman T, Stephenson JN, Lester R, Perry S. The removal of phosphorus during wastewater treatment: A review. Environ Pollut. 1988;49(3):183-233. DOI: 10.1016/0269-7491(88)90209-6.

[3] Wilén BM, Jin B, Lant P. Relationship between flocculation of activated sludge and composition of extracellular polymeric substances. Water Sci Technol. 2003;47(12):95-103. http://wst.iwaponline.com/content/47/12/95.

[4] Wilén BM, Lumley D, Mattsson A, Mino T. Relationship between floc composition and flocculation and settling properties studied at a full scale activated sludge plant. Water Res. 2008;42(16):4404-4418. DOI: 10.1016/j.watres.2008.07.033.

[5] Fuhs GW, Chen M. Microbiological basis of phosphate removal in the activated sludge process for the treatment of wastewater. Microb Ecol. 1975;2:119-138. DOI: 10.1007/BF02010434.

[6] Eikelboom DH. Process Control of Activated Sludge Plants by Microscopic Investigation. London: IWA Publishing; 2000.

[7] Jenkins D, Richard MG, Daigger GT. Manual on the Causes and Control of Activated Sludge Bulking, Foaming, and other Solids Separation Problems. London: IWA Publishing; 2003. 
[8] APHA Standard Methods for the Examination of Water and Wastewater. 22nd ed. Washington. DC. USA: American Public Health Association, American Water Works Association, Water Environment Federation; 2012. https://www.standardmethods.org/.

[9] Machnicka A. Asymilacja i uwalnianie fosforu przez mikroorganizmy nitkowate w procesach oczyszczania ścieków [Assimilation and release of phosphorous by filamentous microorganisms in wastewater treatment processes]. Rozprawa habilitacyjna. Bielsko-Biała: Wyd Akad Techn Humanist.; 2006.

[10] Pommerville JC. Fundamentals of Microbiology, Tenth Edition. Burlington, USA: Jones \& Bartlett Learning; 2014. http://www.jblearning.com/catalog/9781449688615/.

[11] Bitton G. Wastewater Microbiology. New York: John Wiley Sons Inc; 2005. DOI: 10.1002/0471717967.

\title{
EFEKTYWNOŚĆ BIOLOGICZNEGO USUWANIA FOSFORU PRZEZ BAKTERIE NITKOWATE
}

\author{
Instytut Ochrony i Inżynierii Środowiska \\ Akademia Techniczno-Humanistyczna w Bielsku-Białej
}

\begin{abstract}
Abstrakt: Usuwanie fosforu w oczyszczalniach ścieków przebiega w procesach: chemicznej precypitacji, biologicznego oczyszczania oraz jednoczesnym strącaniu i akumulacji. Jednym z głównych problemów wysokich stężeń fosforu w środowisku wodnym jest eutrofizacja. Kłaczki osadu czynnego mają heterogenną strukturę, w skład której wchodzą różnorodne mikroorganizmy. Normalnym składnikiem osadu czynnego są bakterie nitkowate mające zdolność asymilacji fosforu. W przedstawionych badaniach starano się określić zdolność wyizolowanych z piany osadu czynnego bakterii nitkowatych do kumulacji fosforu.
\end{abstract}

Słowa kluczowe: organizmy nitkowate, ścieki, piana osadu czynnego, fosfor 